\title{
The contribution of calcareous algae to the biogenic carbonates of the continental shelf: Pontian Islands, Tyrrhenian Sea, Italy
}

\author{
Valentina Alice BRACCHI \\ Daniela BASSO \\ University of Milano-Bicocca, \\ Geological Sciences and Geotechnologies Department, \\ Piazza della Scienza 4, I-20126 Milano (Italy) \\ v.bracchi@campus.unimib.it \\ daniela.basso@unimib.it
}

KEY WORDS

Western Pontian Islands, Tyrrhenian Sea, carbonate mineralogy, calcareous algae, carbonate accumulation, coralline carbonate production rate.
Bracchi V. A. \& Basso D. 2012. - The contribution of calcareous algae to the biogenic carbonates of the continental shelf: Pontian Islands, Tyrrhenian Sea, Italy. Geodiversitas 34 (1): 61-76. http://dx.doi.org/10.5252/g2012n1a4

\begin{abstract}
This contribution discusses current carbonate deposition in the channel between the Ponza and Palmarola islands and along the western coast of Palmarola, focusing on the quantitative contribution of biogenic carbonate and in particular on the production and accumulation of carbonates by coralline algae. Seventeen out of 150 grab samples have been selected as representative of the main sedimentary features facies of the seafloor between 30 and $100 \mathrm{~m}$ of water depth (wd). They were analyzed using XRD and EDTA titration. Thin sections of the same samples were made to identify their biogenic components and to quantify the contribution of calcareous algae to the total sediment. Maximum carbonate production takes place between 40 and $70 \mathrm{~m}$ wd, with the percentage of carbonates ranging between 83.1 and $95.7 \%$. of the total. Multidimensional statistical analyses found two different carbonate facies: the coralline algae facies (CA) occupies $38 \mathrm{~km}^{2}$ between 30 and $70 \mathrm{~m}$ wd, and the carbonate matrix facies (CM) covers $24 \mathrm{~km}^{2}$ between 70 and $100 \mathrm{~m}$ wd. An estimate of the current contribution of algal carbonates to seafloor sediments is about $80 \%$ in the CA facies and $15 \%$ in the $\mathrm{CM}$ facies. The accumulation of total carbonate sediments in the uppermost $2 \mathrm{~cm}$ interval of the CA facies is calculated to be $20566 \mathrm{~g} \mathrm{~m}^{-2}$ and the fraction of coralline carbonate in the superficial 2-cm layer of the CM facies is calculated as $16452 \mathrm{~g} \mathrm{~m}^{-2}$. The production rate of the mean $7 \%$ live coralline covers ranges between 7.91 and $31.64 \mathrm{~g} \mathrm{~m}^{-2} \mathrm{yr}^{-1}$.
\end{abstract}




\author{
MOTS CLÉS \\ Îles Pontines \\ occidentales, \\ mer Tyrrhénienne, \\ minéralogie du carbonate, \\ algues rouges calcifiantes, \\ accumulation de \\ carbonate, \\ taux de production \\ de carbonate algal.
}

\begin{abstract}
RÉSUMÉ
La contribution des algues calcaires aux carbonates biogéniques du plateau continental: îles Pontines, mer Tyrrhénienne, Italie.

Les dépôts de carbonates du canal entre les îles de Ponza et Palmarola et le long de la côte ouest de Palmarola ont été étudiés, en particulier la contribution quantitative du carbonate biogénique et la production et l'accumulation de carbonate par les algues rouges calcifiantes. Dix-sept échantillons ont été sélectionnés parmi 150 prélèvements par benne et analysés par XRD et titrages EDTA comme étant représentatifs des principales caractéristiques sédimentologiques du fond entre 30 et $100 \mathrm{~m}$ de profondeur. Des sections minces ont été préparées pour définir les composants biogènes et quantifier la contribution des algues rouges calcifiantes au sédiment total. La production de carbonate est maximale entre 40 et $70 \mathrm{~m}$ et le carbonate total varie entre 83,1 et $95,7 \%$. Deux faciès carbonatés différents ont été reconnus sur la base des analyses statistiques multivariées: le faciès des algues rouges calcaires (CA) occupe $38 \mathrm{~km}^{2}$, dans un intervalle bathymétrique de 30 à $70 \mathrm{~m}$, et le faciès de la matrice carbonatée (CM) occupe 24 $\mathrm{km}^{2}$, entre 70 et $100 \mathrm{~m}$ de profondeur. L'estimation de la contribution actuelle du carbonate algal aux sédiments du fond est de $80 \%$ pour le faciès CA et de $15 \%$ pour le faciès CM. L'accumulation du carbonate total et du carbonate algal actuel dans les deux centimètres superficiels du faciès $\mathrm{CA}$ atteint respectivement $20566 \mathrm{~g} \mathrm{~m}^{-2}$ et $16452 \mathrm{~g} \mathrm{~m}^{-2}$. Le taux de production des $7 \%$ moyens d'algues rouges calcifiantes vivantes varie entre 7,91 et $31,64 \mathrm{~g} \mathrm{~m}^{-2} \mathrm{yr}^{-1}$.
\end{abstract}

\section{INTRODUCTION}

In the latest decades, the topic of non-tropical shelf carbonate deposits has become more and more important. Previously, in temperate noncarbonate areas, the deposition and accumulation of carbonate deposits was considered exceptional. Chave (1967) was the first to report that carbonate deposition could also occur on non-tropical shelves if terrigenous input is low. Modern non-tropical carbonate sediments are composed almost exclusively of heterozoan skeletal remains (sensu James 1997). The association is characterized by animals like molluscs, benthonic foraminifers, echinoderms, bryozoans, barnacles, sponges, ahermatypic coral, and by plants, like calcareous red algae (Lees \& Buller 1972; Nelson 1988). In the Mediterranean and particularly in the Tyrrhenian Sea, shallow marine soft bottom environments are mainly formed by terrigeneous sediments supplied by fluvial systems and coastal erosion processes (Tortora 1996), al- though various skeletal assemblages can provide an important contribution to present-day shelf carbonate production (Pérès \& Picard 1964; Carannante et al. 1998). Many authors have described modern carbonate depositional systems in the Mediterranean Sea (Pérès \& Picard 1964; Carannante et al. 1988; Canals \& Ballesteros 1997; Fornos \& Ahr 1997, 2006; Betzler et al. 1997; Basso 1998). In this paper, we investigate temperate carbonate shelf sediments in the channel between the Ponza and Palmarola islands and along the west cost of Palmarola (Pontian Islands). The phytobenthic assemblages of the area and the living coralline algae were investigated by Basso (1992, 1994, 1996). An interpretation of coralline algal facies and major environmental factors in the framework of the Mediterranean benthic bionomy is reported in Basso (1998).

This study defines the major patterns of carbonate facies on the Pontian shelf, in order to attain a quantification of the contribution of red calcareous algae to those facies. 


\section{GEOLOGICAL SETTING AND OCEANOGRAPHY}

The Pontian Archipelago is located on the outer margin of the continental shelf in the central Tyrrhenian Sea, seaward of Cape Circeo (Fig. 1). It is formed by five islands subdivided into a western group - Palmarola, Ponza, Zannone - and an eastern group - Ventotene and Santo Stefano (see Fig. 1). The position of the western islands is very critical because the area is disposed along the boundary between a stable platform and a still active slope. Plio-Pleistocene volcanic rocks form the archipelago. Rheolytic to trachytic subaerial and submarine volcanic units crop out in the western islands (Barberi et al. 1967). Volcanic activity started in the early Pliocene consequent on extensional tectonics at the Tyrrhenian margin. The western group formed the emergent portion of a structural high that separates the two intra-slope sedimentary basins of Ventotene and Palmarola (De Rita et al. 1986). A NS trending channel $7 \mathrm{~km}$ wide lies between the islands of Palmarola and Ponza. The channel ranges in depth between 28 and $120 \mathrm{~m}$ wd. The shelf break is between 105 and $160 \mathrm{~m}$ wd. The rate of sedimentation at the Pontian Islands' shelf break can be roughly calculated at about $0.7-0.8 \mathrm{~cm} \mathrm{yr}^{-1}$ based on the AMS radiocarbon dating of four cores (Basso et al. 2006). Large instability phenomena have been recorded in the southwestern sector, on an extremely steep continental slope connecting the continental shelf to the Vavilov abyssal plain (Chiocci et al. 2003). The Mediterranean Sea is an enclosed basin, with thermohaline circulation and oligotrophic conditions, (Hopkins 1999; Pinardi \& Masetti 2000; Bricaud et al. 2002). The Tyrrhenian Sea, one of the western Mediterranean basins, shows a wind-driven circulation and negligible tidal currents. The dominant wind directions and the major storms are directed W-NW (Istituto Idrografico della Marina 1978; Noli et al. 1996) but eastward winds in autumn and winter are reported (Noli et al. 1996).

\section{MATERIAL AND METHODS}

The project "Taphonomy and Sedimentology on the Mediterranean shelf" (TSM project) in-

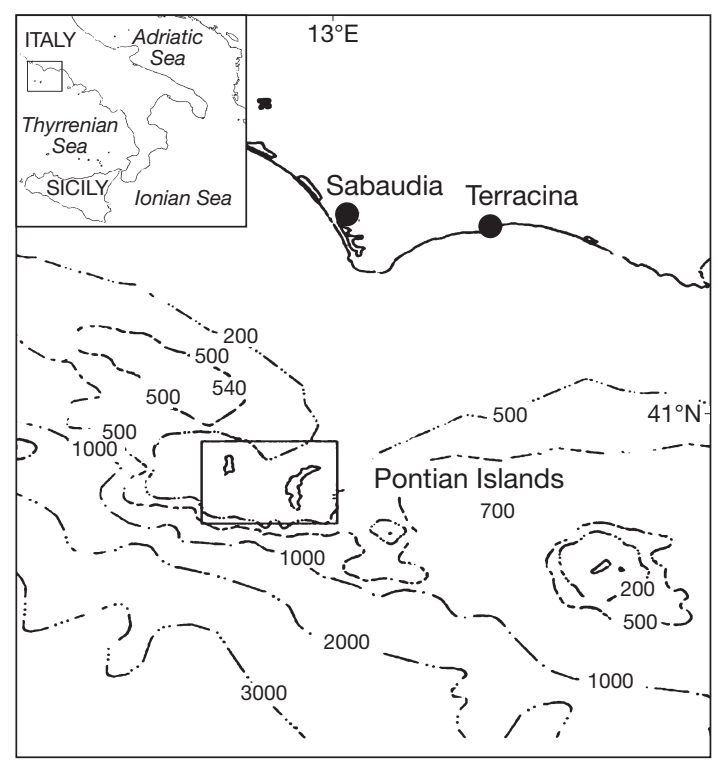

FIG. 1. - Location of western Pontian Islands, Tyrrhenian Sea, Italy. Numbers refer to water depth (in m).

vestigated the sedimentary processes along the Tuscany and Pontian Islands (Tyrrhenian Sea, Italy). During the summer and autumn 1989, two cruises of the RV Minerva sampled the seafloor around the Palmarola and Ponza islands. A total of more than 300 grabs, dredge and core samples were collected. Data on grain size and benthic associations are reported in Corselli et al. (in press). Here we considered two areas: the channel between the Ponza and Palmarola islands and the west Palmarola coast. Only the grab samples collected with a modified Van Veen apparatus 50 litres in volume, are considered here. Taking into consideration available data on location and grain size, 150 grab samples were used to define the major pattern of distribution of benthic assemblages and sediment textures (Fig. 2). Seventeen grab samples of the 150 were selected as representative of the variability of sediment textures and benthic assemblages across the investigated area (Fig. 2; Table 1) and have been analyzed to detect their biogenic components and carbonate phases. Samples were collected at depths ranging between 32 and $100 \mathrm{~m} \mathrm{wd}$. 
TABLE 1. - Position data (UTM coordinates) and depth (in metres) of the 17 selected samples.

\begin{tabular}{lcrrr}
\hline Samples & Position & Depth & Lat. & Long. \\
\hline minau89be91 & W Palmarola & 47 & 405687 & 125018 \\
minau89be92 & W Palmarola & 48 & 405663 & 125018 \\
minau89be105 & W Palmarola & 60 & 405537 & 124938 \\
mine89be107 & SW Palmarola & 104 & 405328 & 124964 \\
mine89be108 & SW Palmarola & 78 & 405431 & 124956 \\
mine89be109 & SW Palmarola & 78 & 405431 & 124956 \\
mine89be118 & Channel & 98 & 405330 & 125107 \\
mine89be119 & Channel & 98 & 405330 & 125107 \\
mine89be141 & Channel & 81 & 405289 & 125295 \\
mine89be143 & Channel & 81 & 405289 & 125295 \\
mine89be144-146 Channel & 68 & 405382 & 125314 \\
mine89be151 & Channel & 32 & 405500 & 125168 \\
mine89be159 & Channel & 46 & 405494 & 125208 \\
mine89be160 & Channel & 54 & 405485 & 125226 \\
mine89be163 & Channel & 61 & 405471 & 125262 \\
mine89be164 & Channel & 61 & 405471 & 125262 \\
mine89be181 & S Palmarola & 61 & 405466 & 125262 \\
\hline
\end{tabular}

A portion of each sample was smashed ground up and analyzed by X-Ray Diffraction (XRD) and ethylene-diamine-tetraacetic acid (EDTA) titrations in order to determine the mineralogical composition of the sediment and to identify the crystalline structure of carbonates (calcite, $\mathrm{Mg}$-calcite and aragonite) (Figs 3; 4). The sediments were poured into small cylinders filled with epoxy resin. The hardened sediment-resin block was removed, UV-glued to glass plates 4.5 $\times 2.7 \mathrm{~cm}$ and ground down to $80-110 \mu \mathrm{m}$. This technique formed artifacts: large aggregates (sand or gravel size) composed of fine particles (silt and clay size) may occur, but their origin is easily recognizable when magnified under binocular. The thin sections were examined under an optical microscope to obtain the percentages of cover derived from corallines and other major benthic components. Nine categories of sedimentary components were identified at $40 \times$ magnification (coralline algae, bryozoans, molluscs, foraminifers, sponges, echinoids, biogenic indeterminate detritus, biogenic carbonate matrix, terrigenous matrix) (Fig. 5). Coralline algae, bryozoans, molluscs, foraminifers, sponges and echinoids were recognized by diagnostic features observable in thin sections (Sholle 1978; Sholle \& Ulmer-
Sholle 2003). We defined the remaining groups as follows: biogenic indeterminate detritus for the fragments showing a typical calcite mineralization but lacking diagnostic features; biogenic carbonate matrix and terrigenous matrix for the detritus in which we could not distinguish and map the individual grains (under 40x), identifying the sediment as carbonate or terrigenous on the basis of EDTA results. The distribution of the nine groups was digitally mapped and quantified on the thin sections (AutoCAD 2008; ArcView GIS version 3.1) (Fig. 6). The identification of coralline algae genera or species was done on the thin sections (Fig. 7).

Hierarchical cluster analysis and non-metric Multidimensional Scaling (MDS) ordination based on the Bray-Curtis similarity of carbonate mineralogy and sediment components (percentage data) of the 17 sediment samples were performed with PRIMER 6 (version 6.1.12; Clarke \& Gorley 2006) (Figs 8; 9). Results of the statistical analysis have been used to identify the major pattern of carbonate facies distribution across the area, and to produce a map of the areal distribution of these patterns (Fig. 10). Sediment density has been calculated as weight $(\mathrm{g}) \times$ volume $^{-1}\left(\mathrm{~cm}^{3}\right)$.

Available data on algal carbonate in Mediterranean sedimentary environments are reported as grams dry weight per unit of surface (Canals \& Ballesteros 1997). In the gravelly sand of the studied area, the maximum diameter of most of the single algal particles (rhodoliths or unattached branches) is $1-3 \mathrm{~cm}$. Therefore, the biogenic sediments currently forming on the seafloor should be confined to a $2 \mathrm{~cm}$-thick layer of sediment used here to calculate the percentage accumulation of algal carbonates. Several authors have reported growth rates for various species of coralline algae in tropical environments or shallow-water (Adey \& Vassar 1975; Potin et al. 1990; Garrabou \& Ballesteros 1999; Frantz et al. 2000; Georgina-Rivera et al. 2004). Data on cultured Mediterranean algae are also available (Basso 1995; Basso \& Caragnano 2007; Basso \& Rodondi 2007; Caragnano \& Basso 2009). Basso (1995) estimated a growth rate of 20-25 mm per 200 years for Phymatolithon calcareum (Pallas) 


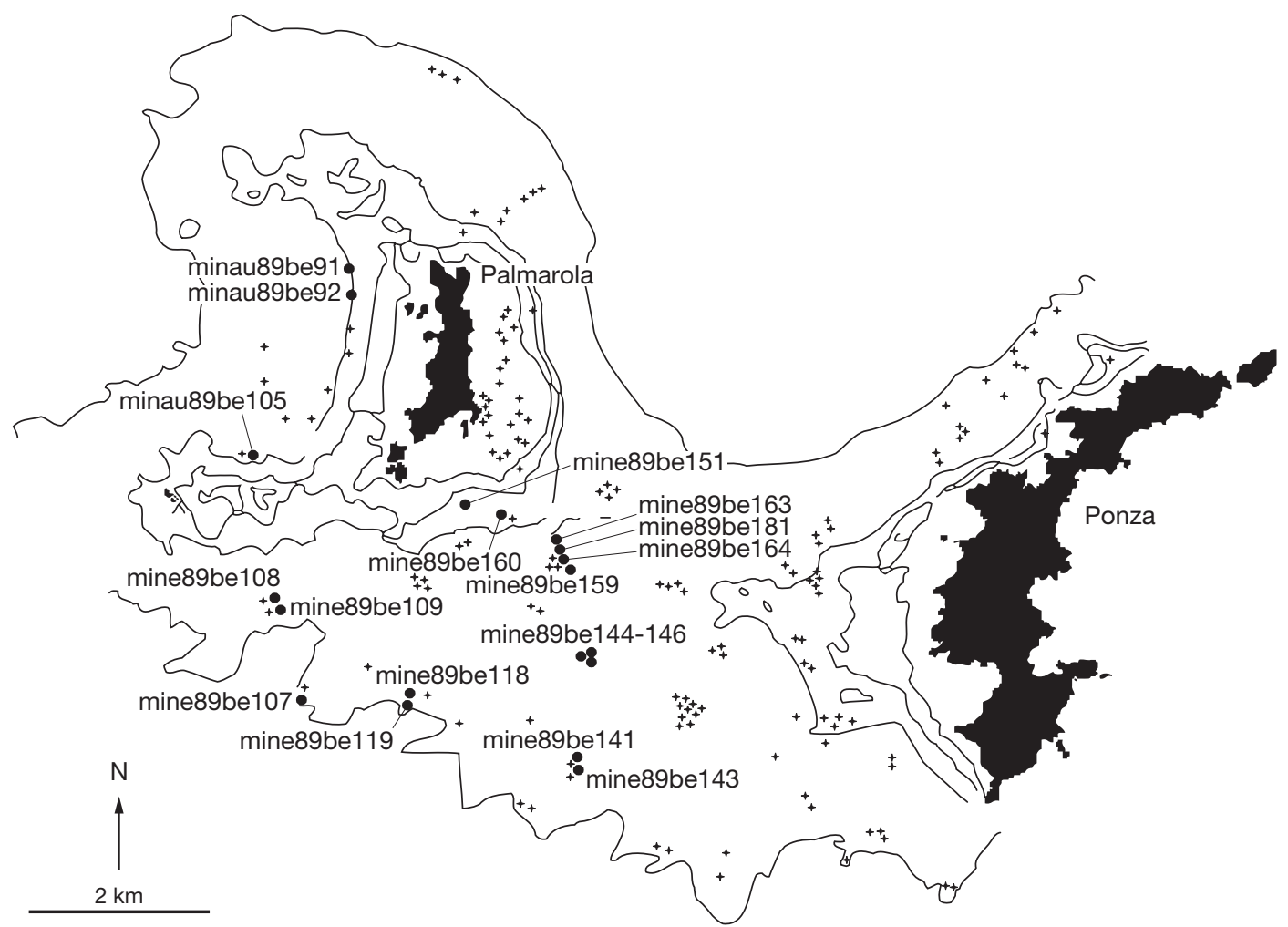

FIG. 2. - Location of samples. Daggers indicate all 150 grab samples. The 17 grab samples selected for study are indicated by circles and the name of the station.

Adey \& McKibbin, 1970, sampled between 35 and $75 \mathrm{~m}$ wd. Caragnano \& Basso (2009) show differences in marginal growth and thickening for Lithophyllum stictaeforme (J.E. Areschoug) Hauck, 1877 and Mesophyllum expansum (Philippi) Cabioch \& Mendoza, 2003 (as M. lichenoides (Ellis) Lemoine, 1918), ranging from $1 \mathrm{~cm}$ per 200 years to $1 \mathrm{~cm}$ per 15 years.

The rates of algal production in the literature range between $464.6 \mathrm{~g} \mathrm{~m}^{-2} \mathrm{yr}^{-1}$ for a coralligenous environment and $210 \mathrm{~g} \mathrm{~m}^{-2} \mathrm{yr}^{-1}$ for maerl beds (Canals \& Ballesteros 1997). We calculated the production rate at the seafloor now on the basis of the percentage cover of living calcareous algae (Basso 1992) and their growth rate. Given the wide range in literature of measured growth-rates of Mediterranean coralline algae, we considered a very conservative figure of $2 \mathrm{~cm}$ per 200 years and an alternative faster growth of $2 \mathrm{~cm}$ per 50 years.

\section{RESULTS}

EDTA TITRATIONS AND XRD

EDTA titrations indicate that all grab samples contain more than $40 \%$ carbonate (Fig. 3), excluding the samples minau89be92 (16.3\%) and mine89be151 (22\%) (Fig. 3). These two samples were taken on the western and southern coasts of Palmarola respectively. The other 15 samples have carbonate percentages ranging from $42.4 \%$ to $96.4 \%$.

Semi-quantitative estimates of the mineralogical phases obtained by XRD analysis are given in Figure 4. High-Mg calcite is the most abundant phase in 14 out of 17 samples. The remaining 3 samples are richer in alkaline feldspars and quartz, with high-Mg calcite a secondary component (Fig. 4). Calcite seldom occurs throughout samples, whereas aragonite is always present in variable abundances. 


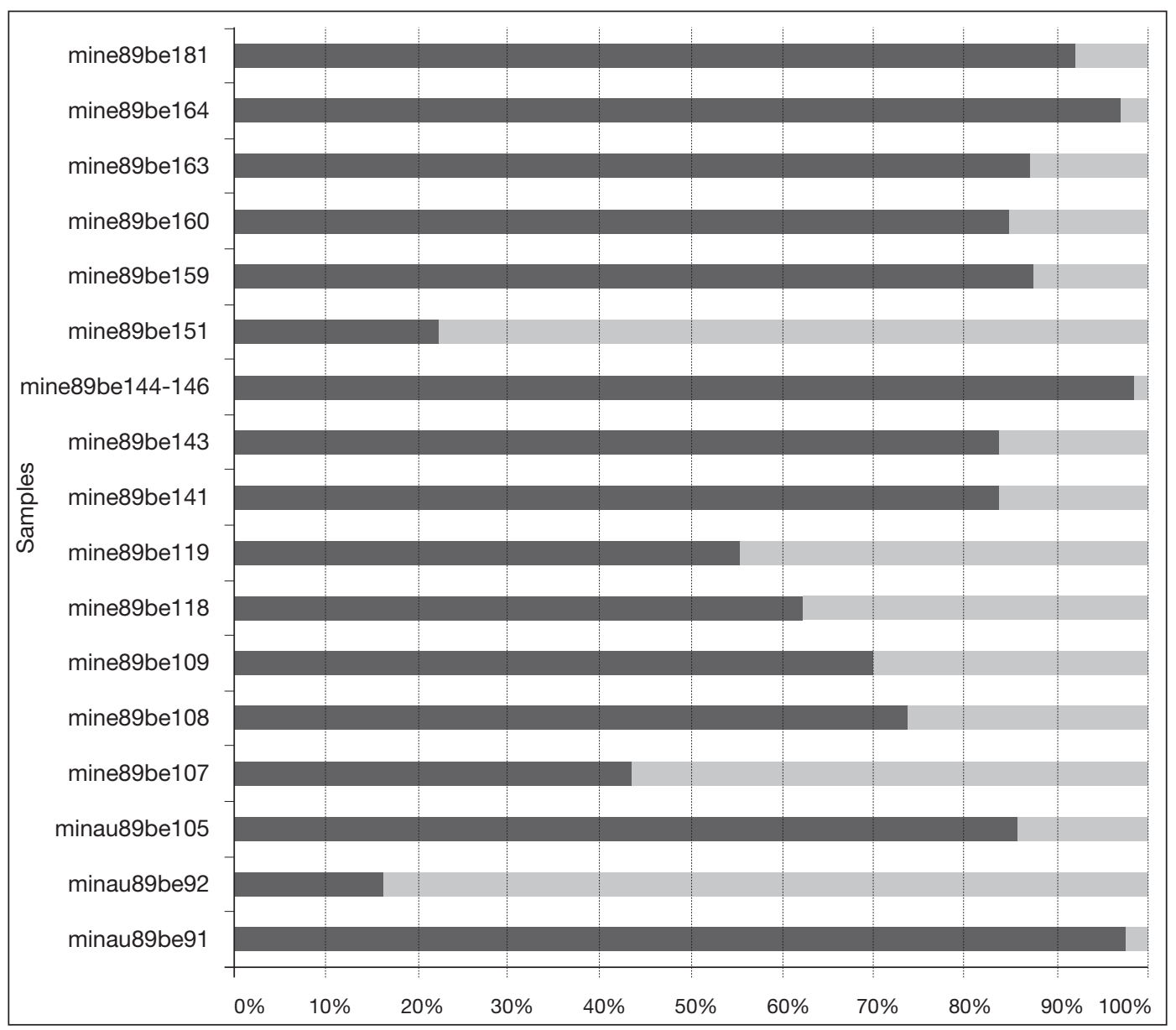

FIG. 3. - EDTA titrations results. Dark grey indicates carbonate percentage. Light grey indicates the percentage of residuals.

\section{THIN SECTIONS}

Samples can be ordered into two major groups on the basis of mapping and by calculation of the percentage of coverage for the 9 categories (Figs 5; 6). Recognizable fragments of dominant coralline algae characterize the first group, with percentage cover always exceeding $30 \%$, and ranging up to $92.5 \%$ (Fig. 6; Table 3 ). The second group is characterized by a dominant matrix content: seven samples are more than $65 \%$ carbonate matrix, and two are more than $90 \%$ terrigenous matrix (Fig. 6; Table 3). Five species of coralline algae have been identified in thin sections: Lithothamnion minervae Basso, 1995, Lithothamnion sp., Titanoderma sp., Mesophyllum sp. and Lithophyllum sp. (Fig. 7).

\section{MULTIVARIATE STATISTICAL ANALYSIS}

Hierarchical cluster analysis and MDS ordination on data from carbonate mineralogy and sediment components show 3 groups, identified with a BrayCurtis similarity of $70 \%$ (Figs 8 ; 9).

One group has been defined as "Terrigenous facies" (T facies). It was found in 2 samples: minau89be92 and mine89be151. They have low carbonate content (less than $22 \%$ on the basis of titrations) and are characterized by a terrigenous matrix (more than $90 \%$ of cover percentage).

The second group has been named the "calcareous algae facies" (CA facies) and comprises 7 samples: 


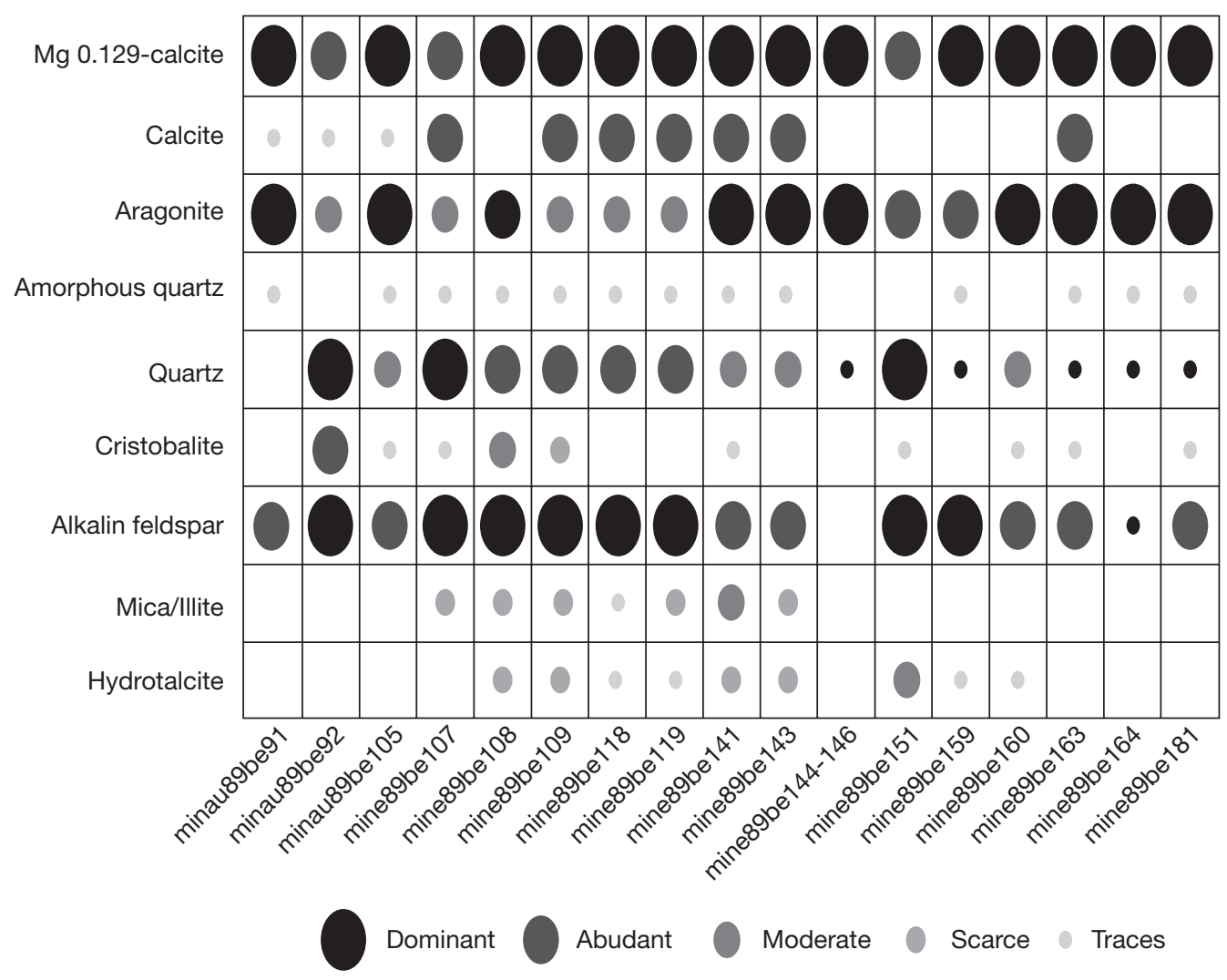

FIG. 4. - Semi-quantitative XRD results. The size of the circles indicates a semi-quantitative estimate of the mineralogical phases.

minau89be91, 105, mine89be159, 160, 164, 181 and 144-146). All have carbonate content higher than $80 \%$, of which the calcareous red algae represent the most abundant group, with a percentage cover higher than $65 \%$ of the total content of carbonate particles, ranging up to $92.5 \%$. The third group has been named the "carbonate matrix facies" (CM facies). Height samples comprise it: mine89be163, 108, 109, 141, 143, 107, 118 and 119. The CM facies is characterized by carbonates ranging from 42.4 to $84.2 \%$ of the total, but it was not possible to distinguish and map the individual grains. The same clusters have been identified in the MDS plot (Fig. 9).

\section{MAPPING, DISTRIBUTION, ACCUMULATION} AND PRODUCTION RATE OF CORALLINE ALGAE Two distinct patterns for carbonate sedimentation have been identified, and mapped, corresponding in general to two bathymetric intervals (Fig. 10). The first bathymetric interval spans 40 to $70 \mathrm{~m}$ wd and delimits the areal distribution of the CA facies. The second interval ranges between 70 and $100 \mathrm{~m}$ wd and is coincident with the areal distribution of the CM facies. The CA facies occupies $38 \mathrm{~km}^{2}$; the CM facies $24 \mathrm{~km}^{2}$ (Fig. 10; Table 2). 80\%, or $30.4 \mathrm{~km}^{2}$, of the CA facies surface is covered by living and dead coralline algae, whereas coralline algae cover only $15 \%$ or $3.6 \mathrm{~km}^{2}$ of the CM facies total surface.

EDTA-titration analyses show that $91 \%$ of the present surface sediment is carbonate, while $9 \%$ is non carbonate (Fig. 11). Coralline carbonate represents $80 \%$ of the total carbonate, including both living and dead coralline thalli and their fragments. The percentage cover of living coralline algae was estimated by Basso (1992) and for the CA facies 
TABLE 2. - Data concerning coralline cover percentage, areal distribution, volume and production rate.

\begin{tabular}{|c|c|c|c|c|}
\hline & \multicolumn{3}{|c|}{ Coralline algae facies } & Carbonate matrix facies \\
\hline Depth (m) & \multicolumn{3}{|l|}{$40-70$} & $70-100$ \\
\hline Granulometry & \multicolumn{3}{|c|}{ Gravelly sand } & Muddy sand \\
\hline Dominant component & \multirow{2}{*}{\multicolumn{3}{|c|}{ Coralline algae }} & Carbonate matrix \\
\hline Facies area $\left(\mathrm{km}^{2}\right)$ & \multirow{2}{*}{\multicolumn{3}{|c|}{$\begin{array}{l}38 \\
80 \%\end{array}$}} & 24 \\
\hline Coralline algae percentage cover & & & & $<15 \%$ \\
\hline Total coralline algae area $\left(\mathrm{km}^{2}\right)$ & \multicolumn{3}{|l|}{30.4} & 3.06 \\
\hline \multirow[t]{2}{*}{ Living coralline algae $\left(\mathrm{km}^{2}\right)$} & \multirow{2}{*}{\multicolumn{3}{|c|}{$\begin{array}{l}\text { living 7\% (2.66 km²) } \\
\text { living 32\% (12.16 km²) }\end{array}$}} & - \\
\hline & & & & - \\
\hline Volume $\left(m^{3}\right)$ & \multicolumn{3}{|c|}{760000} & 480000 \\
\hline Density $\left(\mathrm{g} / \mathrm{cm}^{3}\right)$ & \multicolumn{3}{|l|}{1.13} & 0.066666667 \\
\hline Weight (tons) & \multicolumn{3}{|l|}{858800} & 460800 \\
\hline$\% \mathrm{CaCO}_{3}$ per gram & \multicolumn{3}{|l|}{$91 \%$} & $66 \%$ \\
\hline Coralline algae weight (tons) & \multicolumn{3}{|l|}{625206} & 45619 \\
\hline $\begin{array}{l}\text { Total carbonatic sediment } \\
\text { accumulation }\left(\mathrm{g} / \mathrm{m}^{2}\right)\end{array}$ & \multicolumn{3}{|l|}{20566} & 12672 \\
\hline $\begin{array}{l}\text { Total coralline algae } \\
\text { accumulation }\left(\mathrm{g} / \mathrm{m}^{2}\right)\end{array}$ & \multicolumn{3}{|l|}{16452} & 1900 \\
\hline Production rate $\mathrm{g} \mathrm{m}^{-2} \mathrm{y}^{-1}$ & all & $\begin{array}{l}2 \mathrm{~cm} / 200 \mathrm{y} \\
2 \mathrm{~cm} / 50 \mathrm{y}\end{array}$ & $\begin{array}{r}82 \\
329\end{array}$ & $\begin{array}{l}9.5 \\
38.02\end{array}$ \\
\hline Production rate $\mathrm{g} \mathrm{m}^{-2} \mathrm{y}^{-1}$ & living $7 \%$ & $\begin{array}{l}2 \mathrm{~cm} / 200 \mathrm{y} \\
2 \mathrm{~cm} / 50 \mathrm{y}\end{array}$ & $\begin{array}{r}7.91 \\
31.64\end{array}$ & $\begin{array}{l}- \\
-\end{array}$ \\
\hline Production rate $\mathrm{g} \mathrm{m}^{-2} \mathrm{y}^{-1}$ & living $32 \%$ & $\begin{array}{l}2 \mathrm{~cm} / 200 \mathrm{y} \\
2 \mathrm{~cm} / 50 \mathrm{y}\end{array}$ & $\begin{array}{r}36.16 \\
144.64\end{array}$ & - \\
\hline
\end{tabular}

gives a mean value of $7 \%$ of the total area, with maximum values of $32 \%$ (sample minau89be105) (Fig. 11).

Considering the covering $2 \mathrm{~cm}$-thick sediment layer, the present-day living biogenic interface, the accumulated volume of total coralline algae in the CA facies, both living and dead, is $608000 \mathrm{~m}^{3}$. The accumulation of total carbonate sediments and the fraction of coralline carbonate presently in the covering 2-cm layer on the seafloor are calculated as 20566 and $16452 \mathrm{~g} \mathrm{~m}^{-2}$ respectively.

Using the $7 \%$ living coralline algae as a reference, and assuming a growth rate of $2 \mathrm{~cm}$ per 50 years, the algal production rate is $31.64 \mathrm{~g} \mathrm{~m}^{-2} \mathrm{yr}^{-1}$. Alternatively, with a much slower growth rate of $2 \mathrm{~cm}$ per 200 years, we calculate a present-day coralline carbonate production rate as $7.91 \mathrm{~g} \mathrm{~m}^{-2} \mathrm{yr}^{-1}$.

If the highest observed value of living coralline algae $(32 \%)$ is used, the algal production rate is $144.64 \mathrm{~m}^{-2} \mathrm{yr}^{-1}$ for faster growth rate, and $36.16 \mathrm{~m}^{-2}$ $\mathrm{yr}^{-1}$ for the lowest.

At a growth rate of $2 \mathrm{~cm}$ per 50 years, the rate of all coralline production, living and dead, is $329 \mathrm{~g} \mathrm{~m}^{-2} \mathrm{yr}^{-1}$.

\section{DISCUSSION}

The studied area of the Pontian Islands is a typical mobile substrate of the circalittoral zone, termed "détritique côtier" (DC) in the classification scheme of Pérès \& Picard (1964) (Basso 1994, 1996, 1998). The DC sediment is composed of a mixture of sand, gravel and mud (Blanc 1968). The coarse fraction of the DC sediment is biogenic clasts, produced in situ or derived from nearby environments (coralligenous build-ups, Posidonia meadows, etc.) (Blanc 1968; Pérès 1982). Data on the distribution of benthic assemblages and sedimentary facies of the Pontian Islands (Basso 1998; Altobelli \& Collins 2004; Sañe-Schepisi et al. 2004; Brandano \& Civitelli 2007; Corselli et al. in press) at depths ranging between 30 and $100 \mathrm{~m}$ wd suggest a moderate variability of predominantly sand-sized sediments dominated by biogenic carbonates. Most of the Pontian sediments are a mixture of free algae branches, rhodoliths and coralligenous-derived fragments. In the bathymetric interval between 

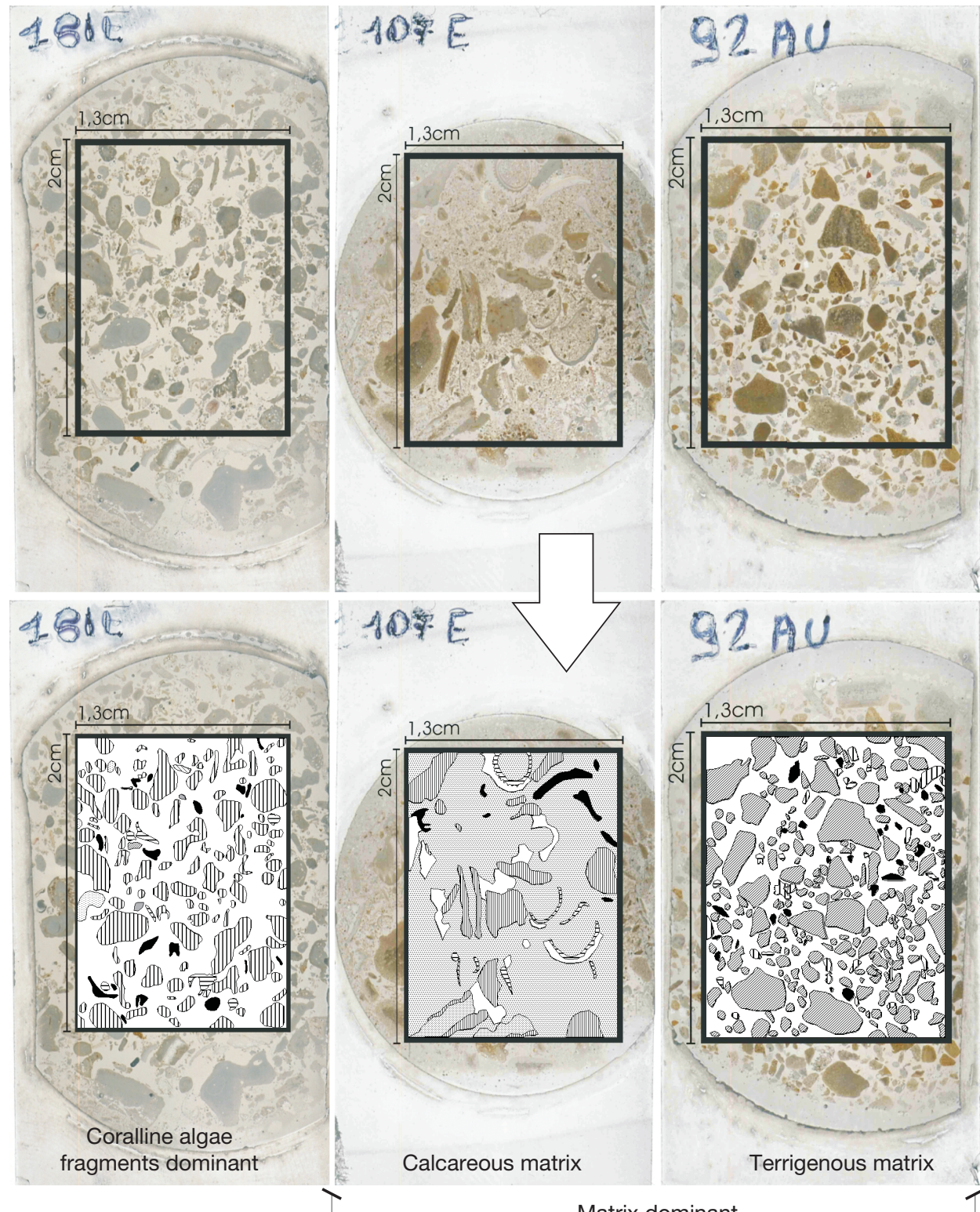

Calcareous matrix

Terrigenous matrix

Matrix dominant

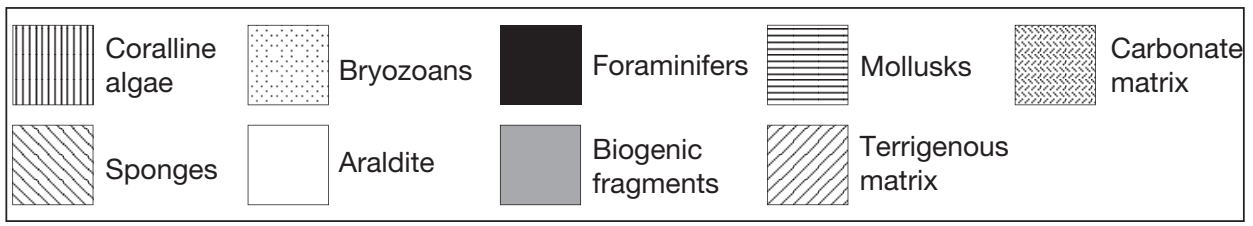

FIG. 5. - Example of thin section mapping. Three mapped thin sections showing the area selected for mapping (above) and the results (below). The textures in the legend indicate the biogenic components identified. On thin section 92AU the apparently coarse, unsorted terrigenous sand is an artifact caused by an Araldite inclusion (see Material and methods). 


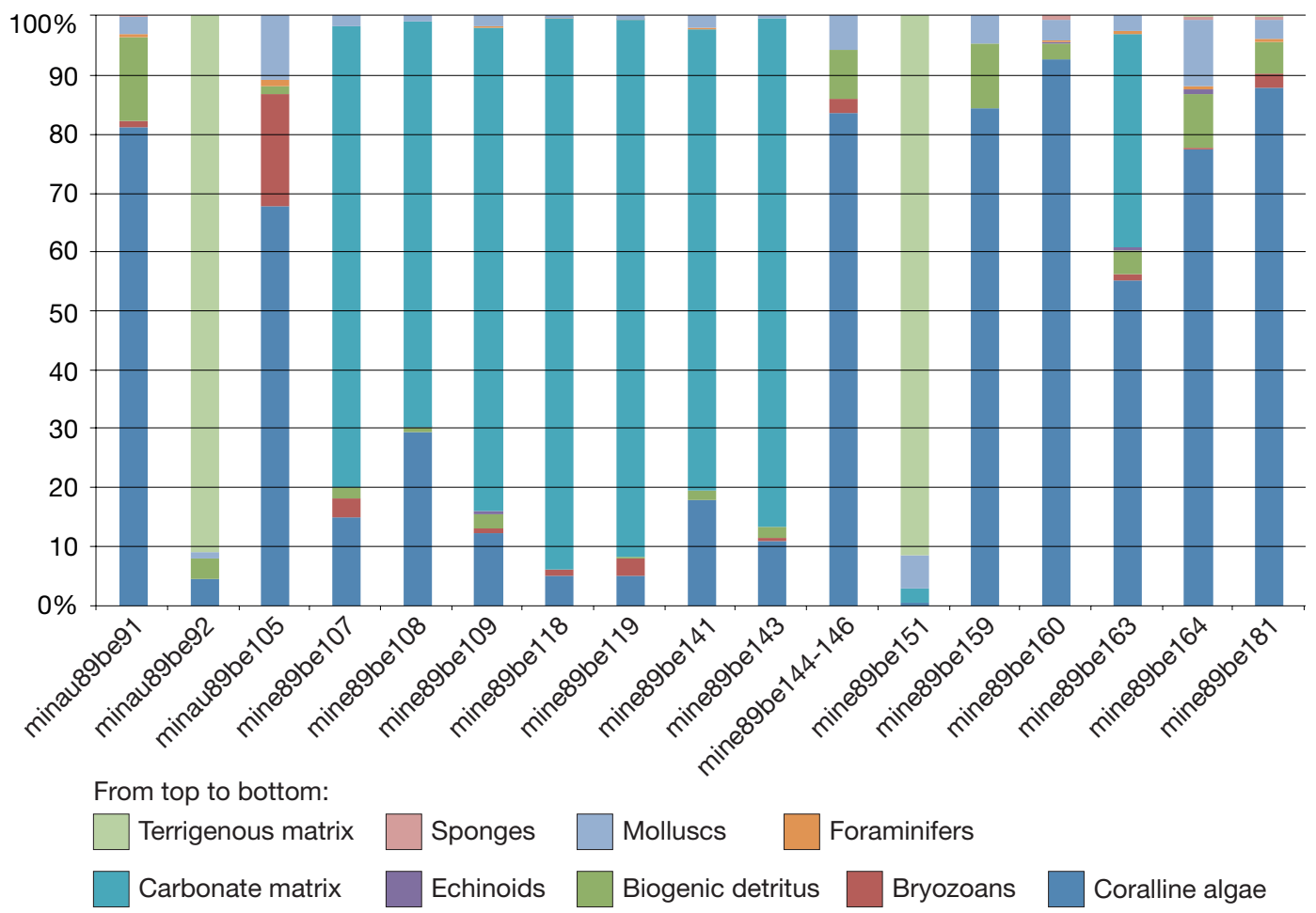

FIG. 6. - Percentage of the sediment cover provided by its components. The legend gives the significance of the several shades of gray. Grey tones indicate the identified biogenic components, as indicated in the legend. Percentages are given in the Table 3.

TABLE. 3. - Percentage of the sediment cover provided by its components. This Table corresponds to the Figure 6.

\begin{tabular}{|c|c|c|c|c|c|c|c|c|c|}
\hline Sample & $\begin{array}{l}\text { Coralline } \\
\text { algae }\end{array}$ & $\begin{array}{l}\text { Bryozo- } \\
\text { ans }\end{array}$ & $\begin{array}{l}\text { Biogenic } \\
\text { detritus }\end{array}$ & Echinoids & $\begin{array}{l}\text { Carbonate } \\
\text { matrix }\end{array}$ & $\begin{array}{c}\text { Fora- } \\
\text { minifers }\end{array}$ & Molluscs & Sponges & $\begin{array}{l}\text { Terrigenous } \\
\text { matrix }\end{array}$ \\
\hline minau89be91 & 81.0 & 1.0 & 14.3 & - & - & 0.4 & 3.0 & 0.3 & - \\
\hline minau89be92 & 4.6 & - & 3.3 & - & - & - & 1.1 & - & 91.0 \\
\hline minau89be105 & 67.6 & 19.0 & 1.4 & - & - & 1.1 & 10.9 & - & - \\
\hline mine89be107 & 15.0 & 3.1 & 2.0 & - & 78.0 & - & 1.8 & - & - \\
\hline mine89be108 & 29.3 & - & 0.9 & - & 68.5 & - & 1.2 & - & - \\
\hline mine89be109 & 12.4 & 0.7 & 2.5 & 0.5 & 81.7 & 0.4 & 1.8 & - & - \\
\hline mine89be118 & 5.2 & 0.8 & - & - & 93.3 & 0.1 & 0.6 & - & - \\
\hline mine89be119 & 5.1 & 3.0 & 0.2 & - & 90.9 & 0.1 & 0.8 & - & - \\
\hline mine89be141 & 18.0 & - & 1.4 & - & 78.2 & 0.2 & 2.2 & - & - \\
\hline $\begin{array}{l}\text { mine89be143 } \\
\text { mine89be144- }\end{array}$ & 10.9 & 0.6 & 2.0 & - & 86.1 & - & 0.4 & - & - \\
\hline 146 & 83.5 & 2.2 & 8.4 & - & - & - & 5.9 & - & - \\
\hline mine89be151 & 0.6 & - & - & - & 2.5 & - & 5.4 & - & 91.5 \\
\hline mine89be159 & 84.2 & - & 11.1 & - & - & - & 4.7 & - & - \\
\hline mine89be 160 & 92.5 & - & 2.6 & 0.3 & - & 0.3 & 3.5 & 0.8 & - \\
\hline mine89be163 & 55.0 & 1.1 & 4.0 & 0.8 & 36.0 & 0.4 & 2.8 & - & - \\
\hline mine89be164 & 77.2 & 0.2 & 9.1 & 0.7 & - & 0.7 & 11.0 & 0.6 & 0.3 \\
\hline mine89be181 & 87.6 & 2.5 & 5.4 & - & - & 0.4 & 3.4 & 0.4 & 0.3 \\
\hline
\end{tabular}



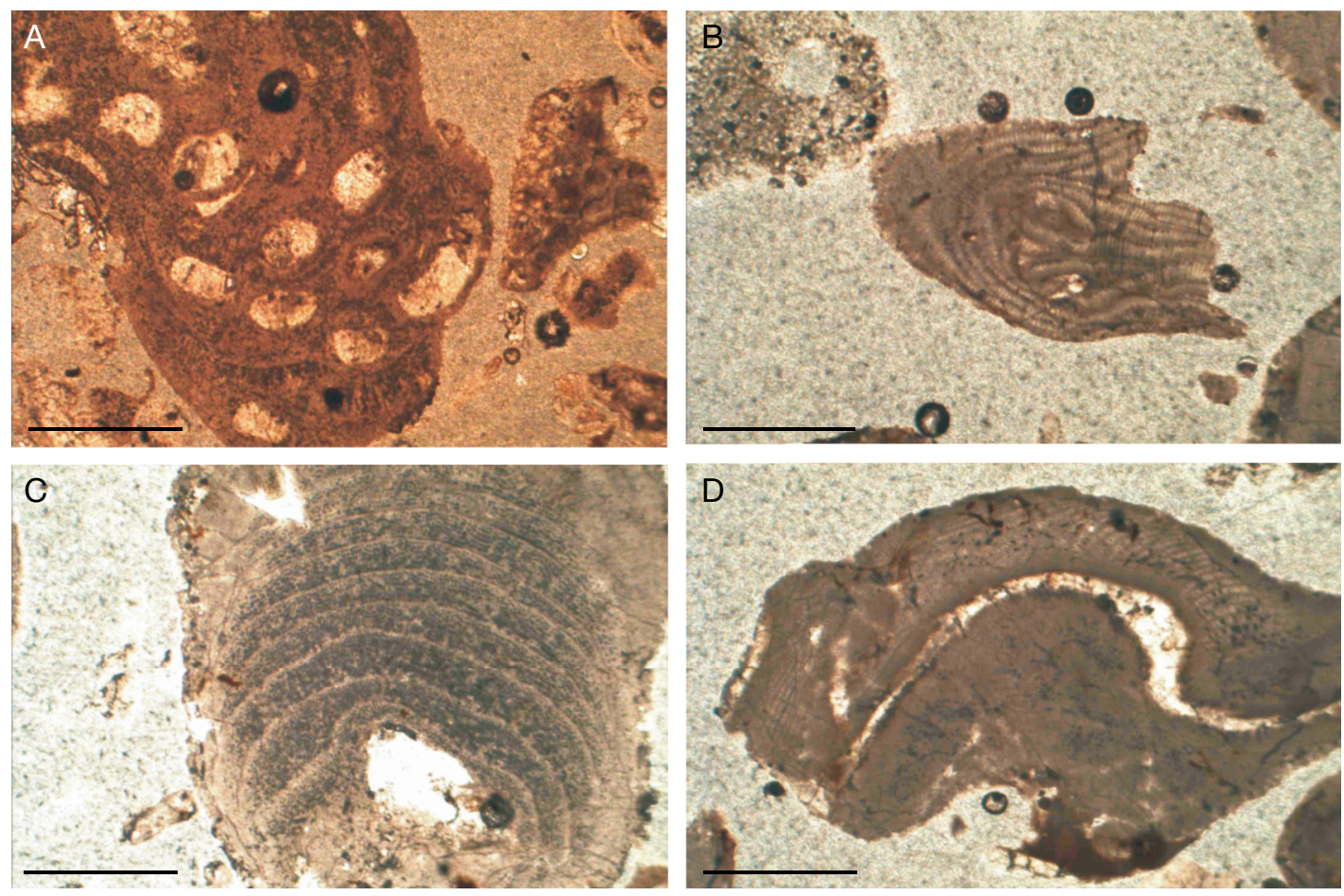

FIG. 7. - Species/genera of coralline algae: A, L. minervae Basso; B, Titanoderma sp.; C, Lithothamnion sp.; D, Mesophyllum sp. Scale bars: $500 \mu \mathrm{m}$.

32 and $100 \mathrm{~m}$ wd, the total carbonate is more than $80 \%$ of quasi-current sediment, and in particular, the highest percentages of carbonates were in samples collected between 49 and $81 \mathrm{~m}$ wd. On the contrary, erosion-derived terrigenous detritus is abundant close to coasts at depths shallower than $43 \mathrm{~m}$ wd. Two carbonate facies were identified: the CA facies and the CM facies (Fig. 10). These facies represent two aspects of the same carbonate-dominated sedimentary realm. Coralline algae play the major role in carbonate biogenic production and consequently the high$\mathrm{Mg}$ carbonate phase is predominant. Coralline algae occupy $30.4 \mathrm{~km}^{2}$ in the area comprised between 40 and $70 \mathrm{~m}$ wd.

The 70-100 m wd range in depth is characterized by the carbonate matrix (CM) type, although abundant coarse algal fragments occur, as reported in literature (Basso 1998; Altobelli 2002; Brandano \& Civitelli 2007; Corselli et al. in press). The abundance of carbonate matrix in the deepest area of the continental platform may be related to the seafloor saddle morphology that is apt for the generation of gravitational mass movements (Chiocci et al. 2003). Moreover, the saddle morphology of the channel between Ponza and Palmarola islands conveys a water flow sweeping the seafloor. The shallowest and sub-planar portion of the saddle morphology is an optimal environment for the development of a coralline facies, because of the favorable depth and hydrodynamics, and the low input of terrigenous sediment. On the other hand, the steep slopes of the sea bottom to the North and South may be responsible for the sediment displacement in the deepest part of the studied area. It is possible that the CM content facies is partly composed of relict particles. The CM facies is not continuous, for rock outcrops reported in the mapped area (Altobelli 2002; Sañe-Schepisi et al. 2004). 


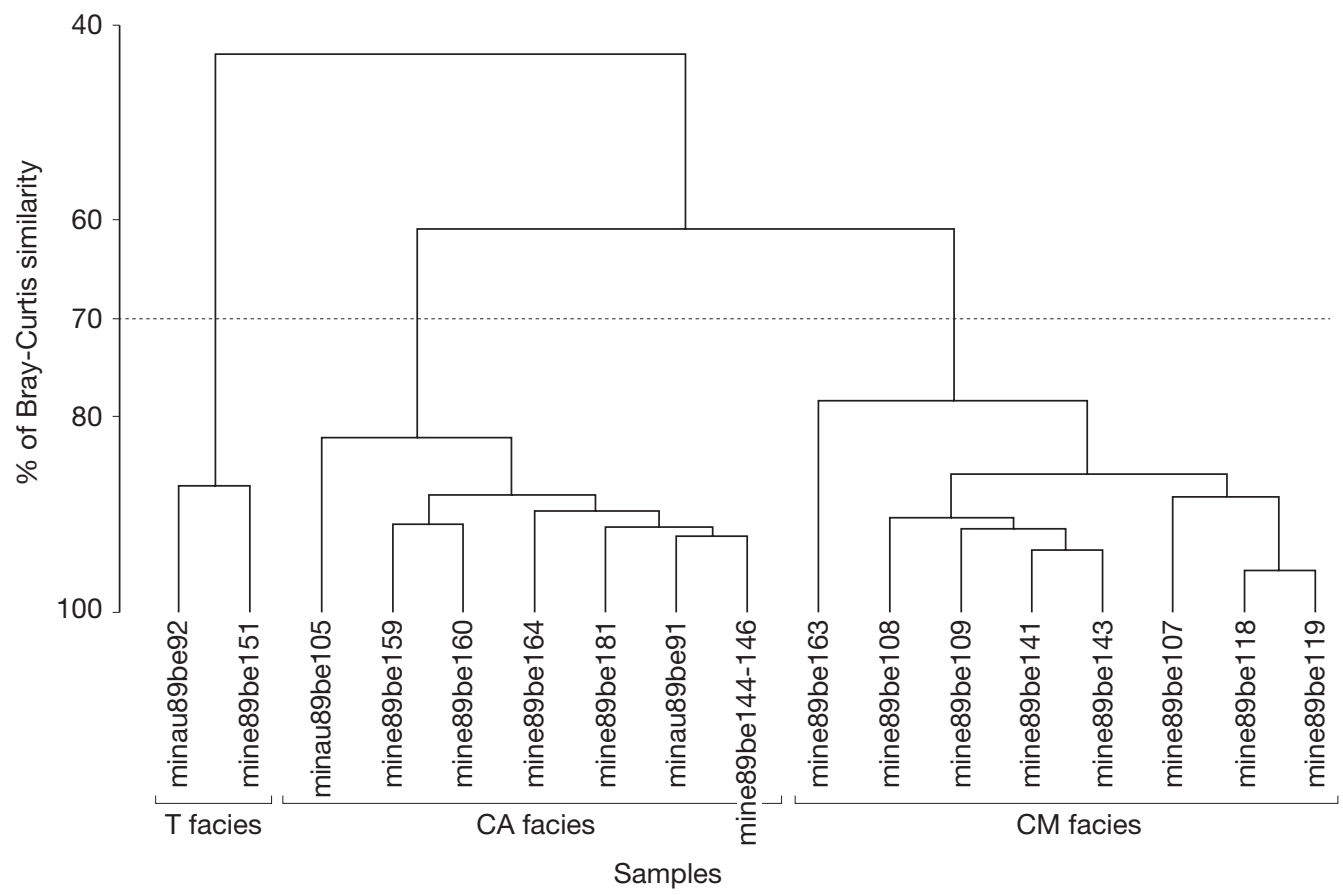

FIG. 8. - Dendrogram from cluster analysis based on Bray-Curtis similarity. A line indicates the level of $70 \%$ of Bray-Curtis similarity. Three clusters have been identified and the name of the corresponding facies is indicated below. Abbreviations: CA, coralline algae; $\mathbf{C M}$, carbonate matrix.

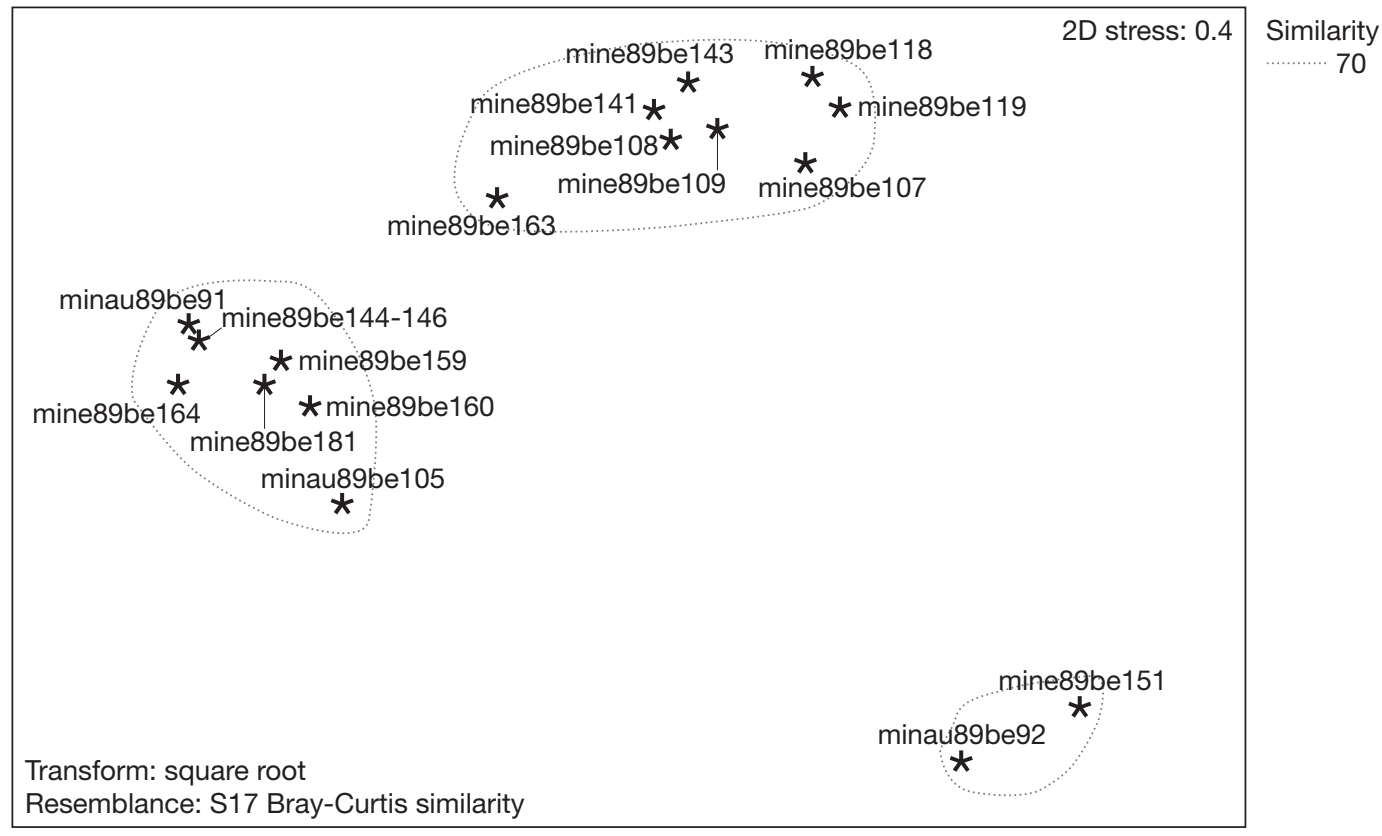

2D stress: 0.4

Similarity

FIG. 9. - Non-metric MDS analysis based on the Bray-Curtis similarity of Figure 8. The override clusters correspond to those of Figure 8. 


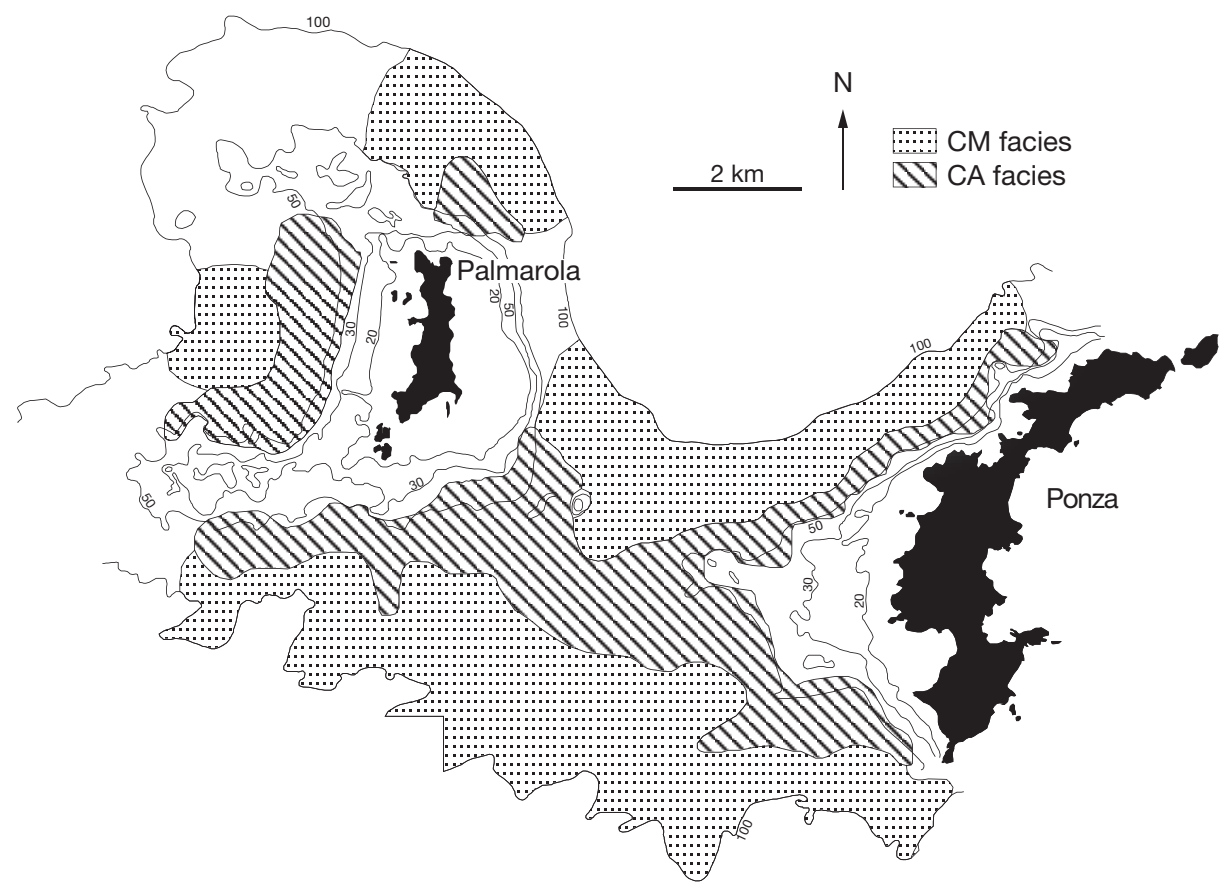

FIG. 10. - Map of the calcareous algae (CA) facies and carbonate matrix (CM) facies. Numbers refer to water depth (in $\mathrm{m}$ ).
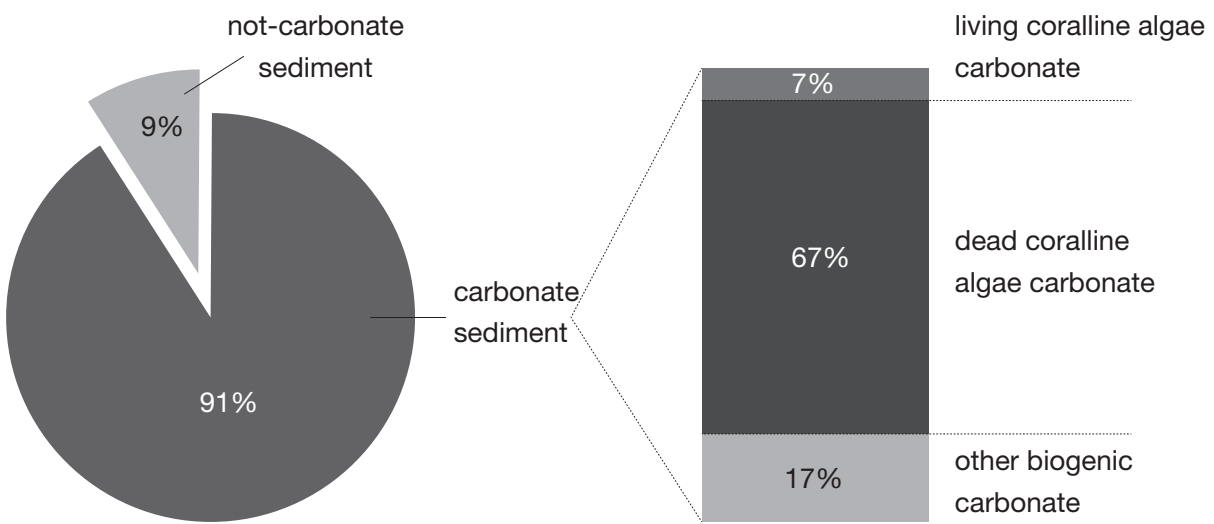

FIG. 11. - Sediment mineralogy and carbonate components: left, sediment mineralogy from EDTA analyses; right, carbonate components from thin section analyses.

Four of the ten facies and sub-facies identified by Brandano \& Civitelli (2007) can be recognized in our analyses of the biogenic components of the western Pontian Islands. The CA facies corre- sponds to F4 ("unattached coralline algal branches gravel"), F2a ("poor sorted skeletal sand") and F5b ("siliciclastic skeletal sand"). In particular, Brandano \& Civitelli (2007) recognized facies 
F4 as the environment with the highest rate of carbonate production rate. The CM facies corresponds to F2a ("poorly sorted skeletal sand") and F5 ("relict sand").

The sedimentary facies of Brandano \& Civitelli (2007) was aimed at provide a detailed description of seafloor sediments, whereas we focused on the total carbonate content and its mineralogy in order to produce an areal and volumetric quantification of coralline algae. Thus, our carbonate facies include more than one of the sedimentary facies of Brandano \& Civitelli (2007).

The production rate of the $7 \%$ mean cover of living coralline algae in CA would yield from 7.91 to $31.64 \mathrm{~g} \mathrm{~m}^{-2} \mathrm{yr}^{-1}$ depending on the rate of production. If we choose the highest level of living coralline algae in CA (32\%), this rhodolith bed (Steller et al. 2003) has an algal production rate between $36.16 \mathrm{~g}$ $\mathrm{m}^{-2} \mathrm{yr}^{-1}$ and $144.64 \mathrm{~g} \mathrm{~m}^{-2} \mathrm{yr}^{-1}$. Canals \& Ballesteros (1997) reported a production rate ranging between $210 \mathrm{~g} \mathrm{~m}^{-2} \mathrm{yr}^{-1}$ for maerl beds and $464 \mathrm{~g} \mathrm{~m}^{-2} \mathrm{yr}^{-1}$ for coralligenous assemblage. Our calculated values of coralline production rate, though lower than those of Canals \& Ballesteros (1997), seem reasonable because we did not investigate the hard substrates, and true maerl does not occur in the area of our investigation. Moreover, the depth range of our CA facies is broad enough to accept the existence of a variable rate of algal carbonate production.

\section{CONCLUSION}

The western Pontian Islands shelf is an area of temperate carbonate deposition. Two carbonate facies (CA and CM) have been identified and represent continental shelf deposition between 40 and $100 \mathrm{~m}$ wd. In particular the CA facies occupies the bathymetric interval from 40 to $70 \mathrm{~m}$ wd, and the CM facies is present only between 70 and $100 \mathrm{~m}$ wd. The contribution of continental sediments is confined to shallow-water, near the islands coasts. On the continental shelf, biogenic activity produces most of the sediments. Sand is the dominant class of the grain-size distribution. Gravel particles are present, especially in samples of CA facies where mud content increases below the $80 \mathrm{~m}$ wd.
Maximum carbonate production takes place between 40 and $70 \mathrm{~m} \mathrm{wd}$, with carbonate content ranging between 83.1 and $95.7 \%$.

Coralline algae are the most important carbonates producer in the area, attaining a cover of $80 \%$ in water depths between 40 and $70 \mathrm{~m}$ (CA facies), that occupies alone more than $30 \mathrm{~km}^{2}$ of the seafloor. Free branches and rhodoliths $1-3 \mathrm{~cm}$ in diameter form the algal assemblage. In the $2 \mathrm{~cm}$-thick layer of sediment that constitutes the current living biogenic interface, the cumulative volume of both alive and dead coralline algae is $608000 \mathrm{~m}^{3}$. In the current $2 \mathrm{~cm}$ layer, the total of carbonate sediments and the fraction of the total made up of coralline carbonate are respectively 20566 and $16452 \mathrm{~g} \mathrm{~m}^{-2}$. Significant living coralline algal cover occurs only in the CA facies, for which we calculated a production rate of 7.91$31.64 \mathrm{~g} \mathrm{~m}^{-2} \mathrm{yr}^{-1}$.

In the deeper bathymetric interval (CM facies) calcareous red algae occupy $3.6 \mathrm{~km}^{2}$ of seafloor, in muddy sand characterized by abrasion, bio-erosion and recrystallization (Brandano \& Civitelli 2007). The percentage of biogenic carbonate in this interval has a mean value of $66 \%$. The recognized algal contribution is lower than $15 \%$ of total carbonates.

We quantified the areal distribution, the production rate and the sediment contribution of coralline algae in the Pontian area, in order to demonstrate their role in the carbonate budget of the present Mediterranean shelf. In non-tropical environments, coralline algae must be considered one of the most important producers of biogenic sediment, particularly in areas where terrigenous input is minimal.

\section{Acknowledgements}

We thank A. Caragnano for help in laboratory analyses and L. Galimberti for mineralogical and chemical analyses. We are grateful to M. Brandano for his suggestions and revision of a first draft of the manuscript. Financial support for V. Bracchi was provided by Italian MIUR as a PhD fellowship. This work was supported by Fondo Integrativo Speciale per la Ricerca (FISR) Bando 2001, project VECTOR, line 7 , in collaboration with ISPRA. 


\section{REFERENCES}

ADEY W. H. \& VASSAR J. M. 1975. - Colonization, succession and growth rates of tropical crustose coralline algae (Rhodophyta, Cryptonemiales). Phycologia 14: 55-69.

Altobelli C. 2002. - Caratterizzazione morfologica e sedimentologica della piattaforma continentale e della scarpata superiore circostanti l'arcipelago pontino occidentale. Unpublished PhD thesis, XVIII cycle. Università degli studi di Roma "La Sapienza”, Roma.

Altobelli C. \& Collins L. 2004. - Temperate carbonate sedimentation of Pontine Islands continental shelf (central Tyrrhenian Sea, Italy) related to W Australia extra tropical deposits. 4th Annual conference IGCP Project 464 Continental shelves during the last glacial cycle: knowledge and applications. Roma, Aug. 28-31/2004. Conference abstracts: 1.

Barberi F., Borsi S., Ferrara G. \& InNOCENTI F. 1967. - Contributo alle conoscenze vulcanologiche e magmatologiche delle isole dell' arcipelago Pontino. Memorie della Società Geologica Italiana 17: 581-606.

BASSO D. 1992. - Le rodoficee calcaree dei fondi mobili circalitorali del Mar Tirreno: le "rodoliti" attuali in una prospettiva paleoecologica. Unpublished $\mathrm{PhD}$ Thesis, V cycle. Università Studi Milano, Milano.

BASSO D. 1994. - Phytobenthic communities in the circalittoral soft bottoms of the Tyrrhenian Sea (Mediterranean). Atti del $10^{\circ}$ congresso della Associazione Italiana di Oceanologia e Limnologia, Alassio 4-6 Novembre, 1992: 563-573.

BASSO D. 1995. - Study of living calcareous algae by paleontological approach: the non-geniculate Corallinaceae (Rhodophyta) of the soft bottoms of the Tyrrhenian Sea (western Mediterranean). The genera Phymatoliton Foslie and Mesophyllum Lemoine. Rivista Italiana di Paleontologia e Stratigrafica 100 (4): 575-596.

BASSO D. 1996. - Soft bottom Mediterranean calcareous algae (non-geniculate Corallinaceae): distribution and ecology, in Albertelli G., De Maio A. \& Piccazzo M. (eds), Atti del $11^{\circ}$ congresso della Associazione Italiana di Oceanologia e Limnologia, Genova A.I.O.L., Sorrento 26-28 Ottobre 1994: 225-234.

BASSO D. 1998. - Deep rhodoliths distribution in the Pontian Islands, Italy: a model for the paleoecology of a temperate sea. Palaeogeography, Palaeoclimatology, Palaeoecology 137: 173-187.

BASSO D. \& CARAGNANO A. 2007. - Investigating the growth rate of Mediterranean red calcareous algae (non-geniculate Corallinales). Epitome $6^{\circ}$ forum italiano di Scienze della Terra, Rimini 12-14 settembre 2007. Abstract book: 31.

BAsso D. \& Rodondi G. 2007. - Valutazione del tasso di crescita in coltura delle alghe calcaree Lithophyllum stictaeforme e Mesophyllum lichenoi- des: primi risultati. Biologia Marina Mediterranea 14 (2): 172-173.

Basso D., Morbioli C. \& Corselli C. 2006. Rhodolith facies evolution and burial as a response to Holocene transgression at the Pontian Islands shelf break, in PEDley H. M. \& CARANNANTE G. (eds), Cool-Water carbonates: depositional systems and palaeoenvironmental controls. Geological Society of London, Special Publication 255: 23-34.

BetZler C., BRaCherT T. C. \& Nebelsick J. 1997. The warm temperate carbonate province - a review of facies, zonations and delimitations. Courier Forschungsinstitute Senkenberg 201: 83-99.

BLANC J. J. 1968. — Sedimentary geology of the Mediterranean Sea. Oceanography and Marine Biology: an Annual Review 6: 377-454.

Brandano M. \& Civitelli G. 2007. - Non seagrass meadow sedimentary facies of the Pontinian Islands, Tyrrhenian Sea: a modern example of mixed carbonate-siliciclastic sedimentation. Sedimentary Geology 201: 286-310.

Bricaud A., Bosc E. \& Antoine D. 2002. — Algal biomass and sea surface temperature in the Mediterranean Basin. Intercomparison of data from various satellite sensors, and implications for primary productions estimates. Remote Sensing Environment 81:163-178.

Canals M. \& Ballesteros E. 1997. — Production of carbonates particles by phytobenthic communities on the Mallorca-Menorca shelf, northwestern Mediterranean Sea. Deep-Sea Research, Part 2, Topical studies in Oceanography 44 (3-4): 611-629.

CARAgnano A. \& Basso D. 2009. - Growth rate in culture conditions of some Mediterranean calcareous red algae (non geniculate Corallinales). 6th Regional Symposium IFAA, Abstract book: 22.

Carannante G., Esteban M., Milliman J. D. \& Simone L. 1988. - Carbonate lithofacies as paleolatitude indicators: problems and limitations. Sedimentary Geology 60: 333-346.

CHAVE K. E. 1967. — Recent carbonate sediments: an unconventional view. Journal of Geological Educational 15: 200-204.

Chiocci F. L., Martorelli E. \& Bosman A. 2003. Cannibalization of a continental margin by regional scale mass wasting: an example from the central Tyrrhenian Sea. 1st International Symposium on Submarine Mass Movements and their Consequences, Nice, April 6-11 2003. Geophysical Research, Abstracts 5.

Clarke K. R. \& Gorley R. N. 2006. - PRIMER v6: User Manual/Tutorial. PRIMER-E, Plymouth.

Corselli C., Giacobbe S., Basso D., Spanò N., Rinelli P. \& Martinelli M. in press. - Taphonomy and sedimentology on the Mediterranean shelf: sediments and macrobenthos of the Pontian archipelago. Results of the R/VMinerva cruises MINE (summer 1989) and MINAU (autumn 1989), CONISMA, Roma. 
De Rita D., Funiciello R., Pantosti D., Salvini F., Sposato A. \& Velonà M. 1986. — Geological and structural characteristics of the Pontine Islands (Italy) and implications with the evolution of Tyrrhenian margin. Memorie della Società Geologica Italiana 36: 55-65.

Fornós J. J. \& AHr W. M. 1997. - Temperate carbonates on a modern, low-energy, isolated ramp: the Balearic Platform, Spain. Journal of Sedimentary Research 67 (2): 364-373.

Fornós J. J. \& Ahr W. M. 2006. - Present-Day temperate carbonate sedimentation on the Balearic Platform, western Mediterranean: compositional variation along a low-energy isolated ramp, in PEDLEY H. M. \& Carannante G. (eds), Cool-Water carbonates: depositional systems and palaeoenvironmental controls. Geological Society of London, Special Publication 255: 71-84.

Frantz B. R., Kashgarian M., COALE K. H. \& Foster M. S. 2000. - Growth rate and potential climate record from a rhodolith using C-14 accelerator mass spectrometry. Limnology and Oceanography Bulletin 45: 1773-1777.

Garrabou J. \& Ballesteros E. 1999. — Growth of Mesophyllum alternans and Lithophyllum frondosum (Corallinales, Rhodophyta) in the northwestern Mediterranean. Journal of Phycology 35: 1-10.

Georgina-RivierA M., RiosmenA-Rodriguez R. \& Foster M. S. 2004. - Age and growth of Lithothamnion muelleri (Corallinales, Rhodophyta) in the southwestern Gulf of California, Mexico. Ciencias Marinas 30: 235-249.

HOPKINS T. S. 1999. - The thermohaline forcing of the Gibraltar Exchange. Journal of Marine System 20: 1-31.

ISTITUTO IDROGRAFICO DELLA MARINA (ed.) 1978. Il vento e lo stato del mare lungo le coste italiane e dell'Adriatico. Vol. 1. Coste del Mar Ligure e coste orientali dell'alto e medio Tirreno, Genova.

JAMES N. P. 1997. — The cool-water carbonate depositional realm, in JAMES N. P. \& ClARKE J. (eds), Cool-Water carbonates. Society of Sedimentary Geology, Special Publication 56: 1-20.

LeEs A. \& Buller A. T. 1972. - Modern temperatewater and warm-water shelf carbonate sediment contrasted. Marine Geology 13: M67-M73.
Nelson C. S. 1988. - An introductory perspective on non-tropical shelf carbonates. Sedimentary Geology 60: 3-12.

Noli A., De Girolamo P. \& Sammarco P. 1996. Parametri meteomarini e dinamica costiera del Lazio. Il Mare del Lazio. Università degli studi di Roma "La Sapienza" e Regione Lazio, Assessorato opere e reti di servizi e mobilità: 285-313.

PÉRÈS J. M. \& PICARD J. 1964. - Nouveau manuel de bionomie marine benthique de la Mer Méditerranée. Recueil des Travaux de la Station marine d'Endoume, suppl. 31 (47): 5-138.

PÉRĖS J. M. 1982. — Structure and dynamics of assemblages in the benthal. Marine Ecology 5 (1): 119-185.

PinARDi N. \& MASETTI E. 2000. — Variability of the large scale general circulation of the Mediterranean Sea from observations and modelling: a review. Palaeogeography, Palaeoclimatology, Palaeoecology 158: 153-173.

Potin P., FoCH J. Y., Augris C. \& CABIOCH J. 1990. Annual growth rate of the calcareous alga Lithothamnion corallioides (Corallinales, Rhodophyta) in the bay of Brest. Hydrobiologia 204/205: 263-267.

SAÑE-Schepisi E., ABDelahad N., Basso D. \& CHIOCCI F. 2004. - Rhodolith facies distribution on the Pontine Islands shelf. $4^{\text {th }}$ annual conference IGCP Project 464 Continental shelves during the last glacial cycle: knowledge and applications. Roma, Aug. 28-31/2004. Conference abstracts: 24.

SHOlle P. A. 1978. - A color illustrated guide to carbonate rock: constituents, textures, cements and porosities. American Association of Petroleum Geologists, Memoir 27, $241 \mathrm{p}$.

Sholle P. A. \& Ulmer-Sholle D. S. 2003. - A color guide to the petrography of carbonates rocks: grains, textures, porosity, diagenesis. American Association of Petroleum Geologists, Memoir 77, 461 p.

Steller D. L., RiosmenA-Rodriguez R., Foster M. S. \& RoBERTS C. A. 2003. - Rhodolith bed diversity in the Gulf of California: the importance of rhodolith structure and consequences of disturbance. Aquatic Conservation: Marine and Freshwater Ecosystems 13: S5-S20.

TORTORA P. 1996. — Depositional and erosional coastal processes during the last postglacial sea-level rise: an example from the Central Tyrrhenian continental shelf (Italy). Journal of Sedimentary Research 66: 391-405.

Submitted on 19 October 2010; accepted on 7 December 2011. 